\title{
THE FUTURE OF SCIENCE IN THE ISLAMIC WORLD
}

\section{Sohail Inayatullah}

In Islamabad, while speakers at a recent OIC/Comstech (Standing Committee on Science and Technology) meeting titled "Science in the Islamic Polity in the Next Century" delivered tirades against the West, they conspicuously stood at a podium that boldly displayed the words "Best Western." This postmodern paradox captures the angst of a conference that called for more basic science; more and better textbooks; a science focused on the basic human needs of food, shelter, and energy; a self-sustaining science, independent of external money or models; a "Big Western" science that develops new laser, information, and nuclear technologies; and a science that better reflects the worldview of Islam.

Amidst calls for transformation, even by individuals who had been at the helm of the scientific establishment for the last twenty years, it was clear that science in Muslim nations, particularly Pakistan, had gone in the wrong direction. Even the "correct" decisions resulted in disaster because of science policies committed to "big science." While nations like Malaysia focused on products that had commercial gain or ensured the reduction of power of the feudal class, most Muslim nations remained committed to self-aggrandizement and war (both imaginary and real) with their neighbors. Instead of developing commercial science or local science that could meet basic needs and create better health conditions for women and children, nuclear strategies or "big science" was paramount. The costs incurred by the Muslim nations are now quite evident - terrifyingly low literacy rates, the low number of high school and college graduates, the high number of people suffering from malnutrition, to mention but a few obvious indicators. It seems the effects of external and internal colonialism remain, as do pre-Islamic dynastic battles.

In the midst of the utter failure of "big science" or "western science," there have been calls for the development of Islamic science. Originally,

Sohail Inayatullah is is a research fellow at The Communication Centre, Queensland University of Technology, Australia. 
Islamic science was meant to unleash creativity in science by recovering the traditional categories of tawhïd (unity), 'ilm (knowledge) and khalifah (man's sense of being his Creator's trustee); it was meant to develop a science based on an alternative worldview-one that was not modernist in orientation, that is, not framed around the values of the nationstate, reductionism, methodological individualism, materialism, and military expansionism. However, Islamic science under the terror of the regimes of the 1980 s came to mean the science that legitimates itself through the categories of recent scientific paradigms, this is, the Islamic ontological position. Thus, it'was argued that the relativity theory and the big bang theory had their roots in the Qur'an.

This conflation of the eternal with the temporal is problematic for numerous reasons. First, science is based on episteme or changing boundaries of knowledge. If evidence changes, as it did from the Newtonian to the quantum worldview, what then of the Qur'an? In addition, it misunderstands that knowledge should converge out of the Qur'an and not conclude in the Qur'an. Focused on 'ilm, the Islamic worldview is an invitation to thought, to reflection-but not based on dying or indeed dead modernist categories of nationalism. However, the conflation of Islamic ontology with epistemological Islamic science-or for that matter Hawaiian, Indian, or feminist science-led to attempts to mathematize the inspirational and the sublime, leading to bad science and bad religion.

This is not to say that the Qur'an does not give clues of an alternative worldview more balanced in its ontology, that is, one where existential reality, for example, might simultaneously consist of material and nonmaterial factors.

This conference did then begin to move forward, to lead the way. However, even reviewers managed to damn it without attending it or reviewing conference papers. In addition to developing a critique of Western science and not acceding to an entirely cultural position of Islamic science, the conference touched upon the politics of policy making. Science was not seen merely as a desire to know, that is, a move to the universal, but as a system of thought. Science was seen as an enterprise, one where individual scientists have little control over the larger process, that is, what they discover and how they discover it. In this sense, science is bounded by culture and civilization. A non-Western science, like a non-Western theory of development, would be less committed to an alliance between capital, nation, and science. Imagine a science that empowers individuals, attempts to solve local problems even as it tries to find a niche in global capitalist knowledge systems to become universal in some way.

Unfortunately, not enough was said at the meeting about alternative science. Instead, the meeting was dominated by a critique of the West 
against the backdrop of "Best Western" and historical Muslim glories. One participant even argued that science can only be done by nonMuslims unable to conduct true science. Fortunately we can say that, for most people, Islam is a moral space, pluralistic and tolerant, that provides a defense against modernity. But this moral space is constantly under attack, as instrumental rationality leads to Muslim money going, not for Third World local development, but to speculative markets; it is this rationality that does not allow for the creation of a true community. Thus has the West become ubiquitous. We have internalized it to such an extent that we are willing to accept the assumption that science is valuefree, acultural and apolitical. Revivalist or fundamentalist Islam thus is not a creative response to the "modernist self" but a reaction that merely reinforces the values of the West. In contrast, an Islamic science is precisely about asking "Can a different science be created, one with different research questions, with different ways of working together?" It is different from other non-Western ways of knowing in that it claims to be universal as well, in that its results are reproducible.

However, while delegates at the meeting debated the positions of Islamic science, Western science, Islamic ontological science, and the world political economy (which frames who gets what), new technologies promise to transform the ground of the debate. For example, developments in genetic engineering soon promise to transform the private space of our individual genes to public space where they can be bought and sold. Not only will plants and other resources be patented by the technologically advanced-so will our very selves. Not only will the natural, but even the conventional view of reality-considered stable for centuries-will be undermined. Virtual reality, epistemological deconstruction, cultural melange-all challenge the view that there is an essential Reality. Because of computer developments it will soon be difficult to distinguish between what is man-made and what is naturally occurring. The view that Man is the center of all things is equally contentious with challenges from feminist perspectives as well as perspectives that remind us that plants, animals, and robots (technologies) have equal demand on our conceptual space. Finally, sovereignty has become riddled with holes: God, nation, and self appear far more liminal then they have for centuries.

While it is impossible to predict precisely how these transformationsthe end of the natural, the real, Man, and sovereignty - will play themselves out, it is certain that in the postmodern world we will be strangers to each other. For Muslims and others committed to spiritual perspectives of reality, as well as others who live and work at the margins of industrialism and neorealism (the members of social movements and the indigenous peoples), the world already is unfamiliar. The postdecolonization project has been to transform Western reality, or at least to cre- 
ate spaces of familiarity, to recover historical categories silenced by modernization. National projects have been more focused on industrializing within the context of Western liberalism or socialism. We continue to be guided by models of reality that promise more, larger, and grander at the expense of the cooperative, the communal, and the local. Nor do we creatively appropriate that which is foreign, thereby generating new visions of science.

In general, Islamic science (or non-Western science) is about creating new models that are universal and inclusive. It is committed to ethical spaces and action in a world where difference is far more captivating than similarity. However, to survive-for postmodernism does not sufficiently challenge unequal power relations and center-periphery distinctions even as the Third World travels to the First World in the form of immigrants, images, and food-a global ethic, a closure, an agreement must be posited. This remains the debate over the next century. Once the natural, the real, the human, and the sovereign have been made relative, what will the new guiding ethic be? Islamic science and other nonWestern projects lay claim to this future, arguing that colonization has allowed them to creatively internalize the Other and thus create a critical traditionalism that can move the planet forward.

While the conference began with the debate of these issues, it concluded with a specific discussion of the science policies of Muslim nations. Clearly a transformation in science policy at the very top would be ideal: A commitment to science and technology, basic education, and literacy. Specifically, this means scholarships, creating science cities such as Anwar Nasim (of the Pakistan Academy of Sciences) has called for; this also means targeting areas that Pakistan can excel in. We are not talking about a nuclear war program but solar and other softer energy systems wherein an Islamic science could flourish. An Islamic science is also about creating a science consciousness, about creating the spirit of inquiry and the search for knowledge, both spiritual and physical. Islamic science is about using tradition to create a new future, not superimposing an imagined past on the body of the present.

But this grand level of development is unlikely. Muslim nations remain feudal and narrow-minded, with precarious political constructs that remain socially unresponsive. Western science has fit perfectly into that paradigm. Even capitalism is preferable to the strangulation of the military-bureaucracy-landlord system. Forgetting the grand level, finding ways for scientists to work together, increasing funding, initiating pilot projects, and other steps are all important. As Foucault has reminded us, power is everywhere, even at small levels. Minor changes that take place in periods of crises can become factors that lead to massive transformation. As complexity and chaos theory asserts, we live in a world of 
many interactions, numerous loops. By applying the appropriate pressure on some of these points, a great deal is possible.

However, merely calling for more of this or that will not be helpful. Bureaucracies continue because they ossify languages that succeed, ensuring that policies eventually fail. We might not have a solution to the angst of a shrinking moral space, but certainly an alternative science and model of development cannot be any worse than the tragedy of the last few hundred years.

\section{Note}

1. Referring to Best Western Motels where the conference was held. 